JURNAL AL BAYAN: JURNAL JURUSAN PENDIDIKAN BAHASA ARAB

p-ISSN 2086-9282 | e-ISSN 2549-1229

\title{
Stylistics of Nida Ilahi and Its Implications in Character Learning
}

\author{
Nunung Nursyamsiah ${ }^{1 *}$, Hikmah Maulani ${ }^{2}$, Shofa Musthofa Khalid ${ }^{3}$ \\ ${ }^{1}$ Arabic Education Study Program Universitas Pendidikan Indonesia, Indonesia \\ ${ }^{2}$ Arabic Education Study Program Universitas Pendidikan Indonesia, Indonesia \\ ${ }^{3}$ Arabic Education Study Program Universitas Pendidikan Indonesia, Indonesia
}

Article History:

Received : May 19, 2021

Revised : June 18, 2021

Accepted : July 20, 2021

Published : December 01, 2021

\section{Keywords:}

Context; Language; Stylistic;

Substance

*Correspondence Address:

nunungnursyamsiah@upi.edu

\begin{abstract}
Nowadays, character learning occupies an important position. There are many studies related to this and the Qur'ān can be a solution in the offer of language and character studies. This study aimed to reveal the way of conveying God (stylistics) to mankind contained in the Qur'ān. A qualitative approach was used with narrative inquiry. The data collection technique was done by analyzing the text of the document which was Al-Maidah verse 90 and 105, also An-Nisa verse 43, which was then analyzed for the data trustworthiness, consistency of research data, the possibility for generalization, neutrality, in a grounded theory research. The results of this study found 3 ways of conveying God to humans in the form of prohibitions or orders, the three appeals are as follows: first, in conveying the order, it is carried out in stages; secondly, the substance conveyed in the message is chosen which is very essential and basic; third, the context chosen is adjusted to the understanding of the aspect. The way God calls His servants with different contexts and appeals can be analyzed so that it is finally adopted as a way of conveying moral messages and character in learning. The results of this study can add to the scientific treasures in character-based language learning.
\end{abstract}

\section{Introduction}

Language learning and stylistics are inseparable. Stylistics can be media in language learning. The scope of stylistics study itself covers the aspects of language with its various styles. The stylistic style can be adopted in the language learning itself. Three of the language styles that are studied in stylistics are at-tanāwub, at-taqdīm wa at-ta'khīr, and al-iltifät. ${ }^{1}$ These three styles of language have actually been discussed in the study of Balaghah, especially Ma'ani. ${ }^{2}$ However, this theory is still limited, stagnant, and not able to accommodate the development of language style itself yet into the concept of language learning.

1 Achmad Khusnul Khitam, 'At-Tanāwub, At-Taqdīm Wa At-Ta'khīr, Dan Al-Iltifāt (Kajian Stilistika Al-Qur'an Dan Puisi Arab)', Mukaddimah: Jurnal Studi Islam 2, no. 1 (2017): 1-18. 
Hence, the researchers aimed to explore the three styles of language above so that it can be understood in accordance with their development in this case is related to the development of language learning based on character education. The function of the Qur'ān is not only for Muslim and their worship ${ }^{3}$, but also for all human beings in general $^{4}$ through one of the characteristics of the stylistic aspect ${ }^{5}$ with deeper variations ${ }^{6}$ and different meanings ${ }^{7}$ as a form of study in the form of ideas that can be put into practice $^{8}$. The researchers considered that it is necessary to study stylistics not only the general aspect of language style, but also to deeper analysis, ways and styles of God's language which can be implemented in character education as God calls to His servants.

Related to character education, previous research has been carried out that focuses on the role of Islamic education in mental health ${ }^{9}$, the effectiveness of learning in the classroom ${ }^{10}$ and outside the classroom in the context of learning environmental values, and personal value systems and changes in children's behavior ${ }^{11}$, the relationship between the school environment and human values, attitudes, interests, and motivation ${ }^{12}$, these studies examine how values and character are applied in learning in terms of curriculum concepts and the mental development of students, in this case the researchers examine how character education is taken from literary studies from the form of God's call to explain and prohibit an act through the concept of stylistics. Many research studies

2 Daryanto Setiawan, 'Ilmu Pengetahuan Dalam Al-Qur'an', Al Hadi 3, no. 2 (2018): 641-56.

${ }^{3}$ Novri Hardian, 'Dakwah Dalam Perspektif Al-Qur'an Dan Hadits', Al-Hikmah: Jurnal Dakwah Dan Ilmu Komunikasi 5, no. 1 (2018): 42-52. <https://doi.org/10.15548/al-hikmah.v0i0.92>.

${ }^{4}$ Muhammad Hafidz, 'Memahami Balaghah Dengan Mudah', Ta'limuna 3, no. 2 (2018): 1-17.

5 Wahyu Hanafi, 'Stilistika Alquran: Ragam Bahasa Ayat-Ayat Talab Dalam Diskursus Stilistika', Jurnal Al-Mabsut: Jurnal Studi Islam Dan Sosial 11, no. 1 (2018): 1-19.

6 Jennifer Nycz, 'Stylistic Variation among Mobile Speakers: Using Old and New Regional Variables to Construct Complex Place Identity', Language Variation and Change 30, no. 2 (2018): 175$202<$ https://doi.org/10.1017/S0954394518000108>.

7 David L. Hoover, 'Authorship and Stylistics', The Encyclopedia of Applied Linguistics (2015): 17. <https://doi.org/10.1002/9781405198431.wbeal1457>.

${ }^{8}$ H Zamakhsyari and Hasballah Thaib, 'Tadarus Al-Qur'an : Urgensi, Tahapan, Dan Penerapannya', Almufida 1, no.1 (2016): 21-48.

9 Farideh Hamidi and Zohreh Bagherzadeh, 'Role and Place of Guidance Teacher in Schools', Procedia - Social and Behavioral Sciences 2, no. 1 (2010): 1918-21. <https://doi.org/10.1016/j.sbspro.2010.07.388>.

10 Al Fowehi Hazaa Abdul Karem, Kamisah Osman, and T. Subahan Mohd Meerah, 'The Impact of Module Based Curriculum and Extra-Curriculum Activities' in Developing Environmental Skills among Saudi's Secondary Students', Procedia - Social and Behavioral Sciences 15 (2011): 1756-60. <https://doi.org/10.1016/j.sbspro.2011.03.364>.

11 Mohammad Hassan Asayesh and Bahramizadeh Hamid, 'Examination of Personal Values System and Its Changes among Young People', Procedia - Social and Behavioral Sciences 30 (2011): 1390-94 <https://doi.org/10.1016/j.sbspro.2011.10.270>. 
related to the style of the stylistics themselves on Al-Qur'an have been carried out, namely the analysis of literary and grammatical meanings ${ }^{13}$ as a form of the validity of sacred verses ${ }^{14}$ and the originality. ${ }^{15161718}$ Armed with the mind and heart ${ }^{19}$, other findings about this divine message ${ }^{20}$ reveal that there are simple facts about the characteristics of the Qur'ān ${ }^{21}$ which also explain other findings that the symbolization of the verses of the Qur'ān has four functions, namely the source of religious teachings; an important element in ritual and ceremonial activities; calligraphy ornaments; and the mystic media ${ }^{22}$. Besides, it also encourages the development of science and technology ${ }^{23}$.

This research was conducted to reveal the stylistic concept of how Allah calls His people with the choice of nida in the verse which was then interpreted in character education. The concept of stylistics was studied through $u s l u b$ approach, but the meaning does not separate between literature and non-literature ${ }^{24}$, but the stylistics involved come

12 Anna Uitto, Jelle Boeve-de Pauw, and Seppo Saloranta, 'Educational Factors Explaining 9th Graders Self-Efficacy in Ecological Sustainable Behaviours', Proceedings of the European Science Education Research Association (2013): 1623-1631.

13 Irfan, 'Interpretation of Amanah Verses in the Qur' an Penafsiran Ayat-Ayat Amanah Dalam AlQur' an', Ilmu Al-Qur'an Dan Tarfsir 2, no. 2 (2019): 113-28 <https://doi.org/10.30868/at.v4i02.571>.

${ }^{14}$ Darsitun Darsitun, 'Menakar Ulang Hermeneutika Dalam Studi The Qur'ān Di Era Modern Dan Kontemporer (Pendekatan Sastra, Sejarah Dan Sains)', Islamadina : Jurnal Pemikiran Islam 22, no. 1 (2021): 21. <https://doi.org/10.30595/islamadina.v22i1.6899>.

15 Nur Hizbullah, 'Program Kajian Bahasa Arab Al Qur'an Dan Pemahamannya Dengan Metode Komprehensif’, Jurnal Al-Azhar Indonesia Seri Humaniora 1, no. $4 \quad$ (2014): 267. <https://doi.org/10.36722/sh.v1i4.77>.

16 Arsal, 'Metode Hermeneutika Dan Tafsir The Qur'ān', Alhurriyah : Jurnal Hukum Islam 2, no. 2 (2017): $1-16$

17 Sakinah Fitrianti Baharuddin, 'Pendekatan Semantik Dalam The Qur'ān (Studi Makna Terhadap Ayat-Ayat Kosmologi)', Shaut Al Arabiyyah 6, no. 2 (2019): 177. <https://doi.org/10.24252/saa.v6i2.7162>.

18 A.M. Ismatulloh, 'Ayat-Ayat Hukum Dalam Pemikiran Mufasir Indonesia (Studi Komparatif Penafsiran M.Hasbi Ash-Shiddieqi Dan M.Quraish Shihab)', Fenomena 6, no. 2 (2014): 277. <https://doi.org/10.21093/fj.v6i2.555>.

19 Eko Zulfikar, 'Interpretasi Makna Riya' Dalam Al-Qur'an: Studi Kritis Perilaku Riya' Dalam Kehidupan Sehari-Hari', Al-Bayan: Jurnal Studi Ilmu Al- Qur'an Dan Tafsir 3, no. 2 (2019): $143-57$. <https://doi.org/10.15575/al-bayan.v3i2.3832>.

${ }^{20}$ Istianah, 'Stilistika Al-Qur'an: Pendekatan Sastra Sebagai Analisis Dalam Menginterpretasikan Al-Qur'an', Hermeneutik 8, no. 2 (2014): 369-88.

21 Mohammad Reza Mahmoudi and Ali Abbasalizadeh, 'Statistical Analysis about the Order of Quran's Revelation', Digital Scholarship in the Humanities 34, no. 1 (2019): 152-58. <https://doi.org/10.1093/llc/fqy030>.

22 A Rafiq Zainul Mun'im, 'Tafsir Realis Terhadap Makna Dan Simbol The Qur'ān Bagi Masyarakat Kabupaten Probolinggo', Madania: Jurnal Kajian Keislaman 4, no. 2 (2017): 193. <https://doi.org/10.29300/madania.v21i2.624>.

23 Ahmad Wakka, 'Petunjuk Al-Qur'an Tentang Belajar Dan Pembelajaran (Pembahasan Materi, Metode, Media Dan Teknologi Pembelajaran)', Education and Learning Journal 1, no. 1 (2020): 86-92.

24 Lesley Jeffries, 'Stylistics', The International Encyclopedia of Anthropology (2018): 2. <https://doi.org/10.1002/9781118924396.wbiea1388>. 
from a theoretical orientation ${ }^{25}$. So, Nida Ilahi is not only explained through the stylistic aspect with the style of a divine appeal as the context of this research, but into a context of ideas. Then, it is also based on divine verses in Surah An-Nisa: 43 and Surah Al Maidah: 90 and 105 in the aspect of character education related to the prohibition of immorality. The researchers believed that the divine in this context will contain character values that can be adopted in character-based language learning.

\section{Method}

This research was conducted using a narrative inquiry approach based on the selected data source in the form of a text document, namely Surah An-Nisa: 43, Surah Al-Maidah 90 and 105, this approach was chosen based on the concept of this research approach, which were story telling about the experience and discussions about the meaning. From the story conveyed, in the context of this research, which were the story and the meaning contained in the verses of Surah An-Nisa: 43, Surah Al-Maidah 90 and 105 relating to Allah's prohibition on mankind to commit immorality and hurt themselves and examines the context of the style of language that Allah used. Narrative inquiry is a method approach in social science because of its ability to understand the character and views of things by referring to the narratives that occur or are told in life. Chronological approach was used to analyze such as describing the events that occur in the verse and then specifying and focusing the discussion through a narrative style with a stylistic study.

The data sources are Surah An-Nisa: 43, Surah Al-Maidah 90 and 105, these three verses were chosen as the context of these verses is in the form of God's prohibition against mankind to commit wickedness. In its role, the language of Allah used is understood as an efficacious commandment word that cannot be replaced regarding its prohibition, but the context of the style of language that Allah conveys has a value of beauty so that the meaning conveyed is very right on target. Researchers considered these verses very appropriate to be studied so that finally it can be studied how the commandment in developing character in the learning process.

This research was conducted through the the analysis strategy based on interpretation. Furthermore, it emphasizes the various forms found in the previous

25 Benedict Lin, 'Stylistics in Translation', The Cambridge Handbook of Stylistics (2015): 573-89. <https://doi.org/10.1017/CBO9781139237031.042>. 
narrative research based on the study of Stylistics. The instruments used in data collection include the guidelines for document analysis and for conducting FGDs with experts. The results of the document analysis become the basis for conducting theoretical validity. To check the aspects of credibility (data truth value), dependability (consistency of research data), transferability (possibility for generalization), and confirmability (neutrality) in a grounded theory study, there are steps based on reliable data about the subject, process, and context, a fairly detailed description of the data about the views and actions of the subject, in-depth information about the observed context and meaning, the data held are sufficient to observe the changes that occur, the researchers' view of the observed aspects of the research subject, the data that allows for developing analytical category, data comparison, and the last is conclusion.

\section{Result and Discussion}

The three verses (Table 1) have the same form of nida word but have a different context for each meaning of the verse. The details are as follows:

Table 1. Stylistic Form of Nida Ilahi

\begin{tabular}{|c|c|c|c|c|c|}
\hline Verse & $\begin{array}{l}\text { Nida } \\
\text { word }\end{array}$ & $\begin{array}{c}\text { Kind of } \\
\text { Nida }\end{array}$ & Characteristic & Meaning & Context \\
\hline $\begin{array}{l}\text { An-Nisa: } \\
43\end{array}$ & يا & $\begin{array}{l}\text { Nida } \\
\text { haqiqi }\end{array}$ & $\begin{array}{l}\text { Nida ghair } \\
\text { mandub }\end{array}$ & $\begin{array}{l}\text { an exclamation addressed to } \\
\text { people who have reason, } \\
\text { smart and tamyiz. }\end{array}$ & $\begin{array}{l}\text { Munada or the intended } \\
\text { exclamation is to the } \\
\text { believers }\end{array}$ \\
\hline $\begin{array}{l}\text { Al- } \\
\text { Maidah: } \\
90\end{array}$ & يا & $\begin{array}{l}\text { Nida } \\
\text { haqiqi }\end{array}$ & $\begin{array}{l}\text { Nida ghair } \\
\text { mandub }\end{array}$ & $\begin{array}{l}\text { an exclamation addressed to } \\
\text { people who have reason, } \\
\text { smart and tamyiz. }\end{array}$ & $\begin{array}{l}\text { Munada or the intended } \\
\text { exclamation is to the } \\
\text { believers }\end{array}$ \\
\hline $\begin{array}{l}\text { Al- } \\
\text { Maidah: } \\
105\end{array}$ & يا & $\begin{array}{l}\text { Nida } \\
\text { haqiqi }\end{array}$ & $\begin{array}{l}\text { Nida ghair } \\
\text { mandub }\end{array}$ & $\begin{array}{l}\text { an exclamation addressed to } \\
\text { people who have reason, } \\
\text { smart and tamyiz. }\end{array}$ & $\begin{array}{l}\text { Munada or the intended } \\
\text { exclamation is to the } \\
\text { believers }\end{array}$ \\
\hline
\end{tabular}

The nida sentence in this verse (An-Nisa : 43) is 'يا أيها الذين آمنوا'. Conceptually, the type of nida presented is the letter يا which means an exclamation to those who are near or far. As for the nature of the verse, it includes Nida haqiqi, which is an exclamation addressed to people who are mindful, smart and tamyiz, because basically the message of nida is only intended for people who have healthy mind. Only an 
intelligent person can receive and capture the message contained in nida. In this context, Munada or an intended exclamation is to the believers.

Furthermore, the characteristic of nida with the meaning of an appeal to near and far, the nida in this verse belongs to the category of nida ghair mandub, which is an exclamation addressed to a distant interlocutor and a similar person to a distant interlocutor or addressed to a close interlocutor. It is considered as a special category of Nida al-Mu'minin because the Munada is categorized as believers. From the context of the exclamation sentence, the verse is continued by using Nahyi that is presented as follows:

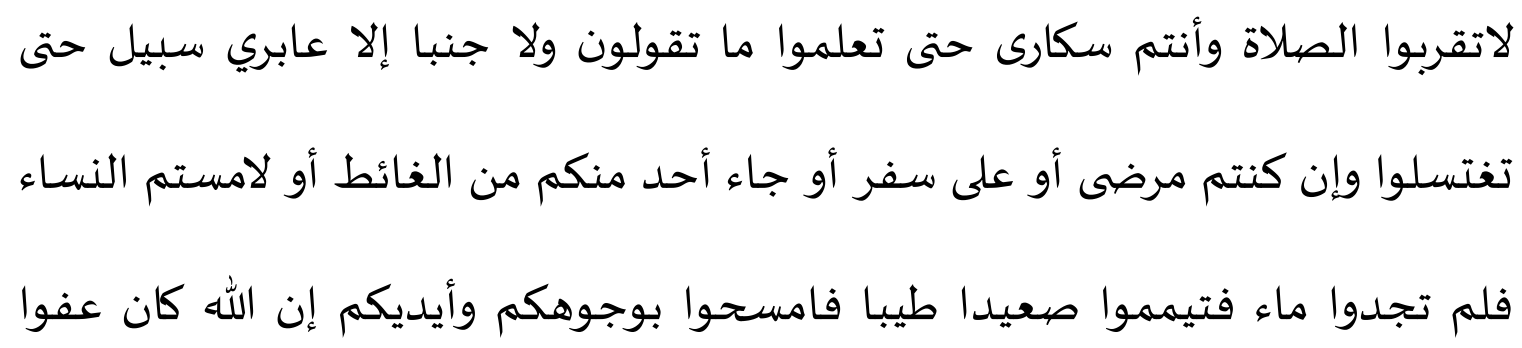

According to this context, the meaning of nida is الإغ (encouraging or suggesting). It is equivalent to the meaning of nahyi, which is to prevent or prohibit. The meaning is a sentence that contains a prohibition on something that is done. In this verse, Allah explicitly used nahyi, so it can be interpreted that this verse emphasized absolute certainty in the form of a prohibition without exception for every believer not to worship while being intoxicated. Allah explained that it was haram by using the prohibition word for worship, not in the context of prohibiting intoxication. This nida form corresponds to the contextual meaning that has been described previously.

After the form of nida about the prohibition from Allah, then it was followed by an affirmation through the expression about the limits and the explanation about the impact of intoxication. The phrase is "حتى تعلموا ما تقولون" ("until you know what you are saying"), this is the best expression for intoxication, which is not knowing what it is said, because people who are intoxicated in their prayer, they can not concentrate and can not understand what is being said. Then, there is another form of nida in this verse, the 
next prohibition is: ولاجنبا إلا عابري سبيل حتى تغتسلوا )'do not enter mosques in the state of ritual impurity, except while passing through"). It is similar to the previous context of nida, then Allah explains with the expression حتى تغتسلوا (Until you have washed yourself").

Allah did not carry out various prohibitions with one type of nida, but for one context by explaining it through clear explanation without judging. This noble verse is a purification of prayer from the improper implementation, such as being intoxicated until being conscious or knowing what is said, junub until having purification with taking a bath or having hadats until perform ablution unless sick or there is no water. Indeed, Allah has given rukhsah in terms of tayamum and its conditions as a mercy for His servants and compassion for them.

The nida sentence in this verse (Al-Maidah: 90) is 'يا أهها الذين آمنوا'. Conceptually, the type of nida presented is the letter يا which means an exclamation to those who are near or far. As for the nature of the verse, it includes Nida haqiqi, which is an exclamation addressed to people who are mindful, smart and tamyiz, because basically the message of nida is only intended for people who have healthy mind. Only an intelligent person can receive and capture the message contained in nida. In this context, Munada or an intended exclamation is to the believers.

Furthermore, the characteristic of nida with the meaning of an appeal to near and far, the nida in this verse belongs to the category of nida ghair mandub, which is an exclamation addressed to a distant interlocutor and a similar person to a distant interlocutor or addressed to a close interlocutor. It is considered as a special category of Nida al-Mu'minin because the Munada is categorized as believers. According to the context of exclamatory sentence, the verse is continued by using affirmative sentences explaining khmar, gambling, and worshiping idols. The affirmation is by using the concept of inna and khabar inna.

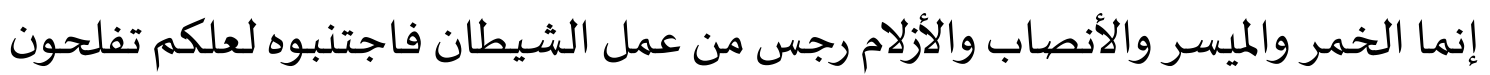

Based on the verse, the meaning of Nida Ilahi aims to provide direction and explanation about the harm of khmar (alcohol), gambling, and worshiping idols. Then 359 | Jurnal Al Bayan: Jurnal Jurusan Pendidikan Bahasa Arab, 13 (2): 353-368 (2021) 
Allah gives further confirmation with fiil amr, which is the command to stay away from alcohol, gambling, and worshiping idols. In the context of this verse, Allah explained directly on the issue of prohibition. In the context of this verse Allah commanded to stay لعلكم ' away from sinful acts that it is an act of Satan, but in the next expression

تفلحون', Allah gave rewards to whoever would avoid the prohibition to get happiness.

The prohibition was carried out because khamr (alcohol) had become a favorite tradition and became a necessity of life for the Arab community at that time. In addition, this drink was known that it had good benefits for humans. If the prohibition was set spontaneously, it would be hard. ${ }^{26}$ Khamr is the main of all kinds of sins (umm al-kabâ'ir) has a tremendous harm to human life. It can cause various kinds of sins arise that can harm the soul, body, mind, and wealth. ${ }^{27}$ Hence, Nida was used once for various sins, Allah commanded to avoid it and made it the reason how happiness is sought.

The nida sentence in this verse (Al-Maidah: 105) is 'يا أيها الذين آمنوا'. Conceptually, the type of nida presented is the letter يا which means an exclamation to those who are near or far. As for the nature of the verse, it includes Nida haqiqi, which is an exclamation addressed to people who are mindful, smart and tamyiz, because basically the message of nida is only intended for people who have healthy mind. Only an intelligent person can receive and capture the message contained in nida. In this context, Munada or an intended exclamation is to the believers.

Furthermore, the characteristic of nida with the meaning of an appeal to near and far, the nida in this verse belongs to the category of nida ghair mandub, which is an exclamation addressed to a distant interlocutor and a similar person to a distant interlocutor or addressed to a close interlocutor. It is considered as a special category of Nida al-Mu'minin because the Munada is categorized as believers. Based on the context of the verse, it can be seen how Allah was giving commandment, which is slightly different from the previous verse. After Munada, Allah gave a polite explanation about

26 Ashar Ashar, 'Konsep Khamar Dan Narkotika Dalam Al-Qu r'an Dan UU', Fenomena 7, no. 2 (2015): 273-96. <https://doi.org/10.21093/fj.v7i2.313>.

27 Arif Jamaluddin Malik, 'Sejarah Sosial Hukuman Peminum Khamr', Al-Daulah: Jurnal Hukum Dan Perundangan Islam 3, no. 1 (2013): 42-56. <https://doi.org/10.15642/ad.2013.3.1.42-56>.. 
the ownership and responsibility of the human soul by humans themselves, this can be seen from the sentence عليكم أنفسكم.

Then, Allah used nahyi. According to this context, the meaning of nida is الإغ راء (encouraging/suggesting). It is equivalent to the meaning of nahyi, which is to prevent or prohibit. The meaning is a sentence that contains a prohibition on something that is done. In this verse, Allah explicitly used nahyi, it can be interpreted that this verse emphasized absolute certainty in the form of a prohibition without exception for every believer not to guard their respective souls from a danger and give themselves harm. This can be observed in the sentence below:

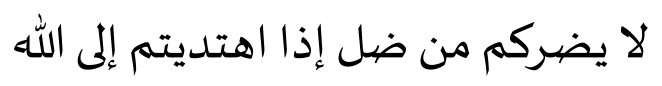

Allah explained that it was haram by using the prohibition to harm them selves, not in the context of prohibiting self-harm explicitly, but by providing an explanation that the soul of each person is individual responsibility. This form of nida corresponds to the contextual meaning that has been described previously. The Nida word in this verse is different from the meaning of Nida in the two previous verses. The prohibition in Nida in this verse is more about suggestion, although this is found in "نفسكم", because it contains the meaning of igra (advice/suggestion). The word "لايضيركم" confirms the answer or prohibition. Allah confirmed that no one would be responsible for the mistakes of other people, it is all based on what that person might do. Nida is placed as a form of advice not to do self-harm, but similar to the two previous verses, Allah places the expression فينبئكم بما كنتم تعملون as an answer to the intended prohibition.

Based on the explanation, it can be interpreted that there is a finding or connection of meaning with the stylistics of Al-Qur'an. Prophet Muhammad (PBUH) and his companions have witnessed many historical events. The special events sometimes even happened among them and needed more explanation from Allah's law point of view 
or being unclear for them, all sourced came from Al-Qur'an. ${ }^{28}$ Islam also concerns a lot to the type of laws (halal, haram, syubhat) through its verses. ${ }^{29}$

Based on the explanation of the meaning in the previous point, it can be interpreted that there is a finding or connection of meaning with the stylistics of AlQur'an. In the meaning of uslub or the style of the Qur'an there is a category of kalam insya ' where these verses contain commands and prohibitions. The kalam inysa' consists of two parts, namely insya thalabi and insya ghairu thalabi. Insya thalabi has the examples such as amr, nahy, istifham, tamanni and nida. The first is amr, acts as a sentence containing a command word.

The second is nahyi, the opposite of amr, which means a sentence that contains a prohibition on something that is done. The third is istifham, which is a sentence that contains a meaningful word asking for understanding or explanation. Then the fourth is tamanni which is a sentence that functions to express a desire for something that is liked, but it is impossible to achieve it. So the meaning of tamanni is a sentence that contains a wish that is impossible to achieve. And the last one is nida which lexically means a call. The meaning is a sentence that contains the meaning of a call. Insha ghairu thalabi is Kalam or sentences that do not require the expected meaning that cannot be achieved when there is a demand, or a sentence that doesn't want something to happen that hasn't happened when it was said.

Another beauty of the meaning is found in the meaning of the verse of His Word: حتى تعلموا ما تقولون ("So that you understand what you are saying”), this is the best expression for intoxication, which is not knowing what it is said, because people who are intoxicated in their prayer, they can not concentrate and can not understand what is being فامسحوا بوجوهكم وأيديكم إنّ الله كان عفوا said. Other contexts such as in the verse

غفورا ("Allah is the Most Pardoning, Most Forgiving”) That is, one of the forms of His forgiveness for you is that he has prescribed tayammum for us and allowed us to pray. Tayammum is done when we run out of water, as a breadth and relief for us.

28 Ahmad Zaini, 'Asbab An-Nuzul Dan Urgensinya Dalam Memahami The Qur'ān ', Hermeunetik 8, no. 1 (2014): 1-20.

29 Alvi Jauharotus Syukriya and Hayyun Durrotul Faridah, 'Kajian Ilmiah Dan Teknologi Sebab Larangan Suatu Makanan Dalam Syariat Islam', Journal of Halal Product and Research 2, no.1 (2019) : 47-48. 
Islam is a religion of $d a^{\prime} w a h$ because all of the Muslims are required to convey the message depends on their abilities. ${ }^{30}$ Character education at school age is indeed an essential topic today, none other than because they have an important role in building society, the state, and civilization. The role of youth is highly expected for the present and future generations ${ }^{31}$. In this case, the Qur'ān asserts that it exists to convince all mankind that they are placed in glory even though they are going through the journey and trials of sin and mistakes, also from these mistakes, human beings can prevent it from each other ${ }^{32}$. Human beings are also trained to understand each other's environment, character, get acquainted with cross cultures so that eventually they can have a sense of tolerance and love for each other ${ }^{33}$.

Through Allah's verses, and how Allah calls upon the Muslims through the commandments and the prohibition by using the certain language styles and contexts. This should be a note that commandments or prohibitions in the learning context must also be right on target by concerning to the aspects of the environmental and even mental conditions of targets. The environment is very influential on the character development. ${ }^{34}$ Adopting from the commandment utterance of Allah related to the context of the prohibition, Allah made a prohibition with clear points about what to avoid, but provided an explanation with precise words so that it was easy to understand why it was forbidden to be adapted to the context of the target.

Furthermore, in learning, the teacher can inspire by giving commandment or prohibitions with clear points and use the context of the students' environment. In relation to language learning, it can be analogous to the concept of nida from these verses using vocabulary that is appropriate to the environment and carried out by the students. However, the teacher should provide a logical explanation or even the impact of what is the intended point of giving commandment. It can also contain alternatives for how to stay away from the prohibition or carry out the commandment. With a context like this, it

30 Arifin Zain, Maimun, and Maimun Fuadi, 'Identifikasi Ayat-Ayat Dakwah', Al Idarah: Jurnal Manajemen Dan Administrasi Islam 1, no. 2 (2017): 167-88.

31 Anshori, Muhammad, ' Pemuda dalam Al-Qur'an dan Hadis', Jurnal Kajian Islam Interdisipliner 1, no. 2 (2019): 227-252.

32 Haris, Abdul, 'Panggilan Quran Kepada Umat Manusia', Jurnal Pengembangan Masyarakat 5, no.5 (2018): 66-80.

33 C.F. Voinea 'Advances in the Simulation-Based Analysis of Attitude Change', European Quarterly of Political Attitudes and Mentalities (EQPAM) 1, no.1 (2012): iv-xi.

34 Adem Tasdemir, Tezcan Kartal, and Zafer Kus, 'The Use of Out-of-the-School Learning Environments for the Formation of Scientific Attitudes in Teacher Training Programmes', Procedia Social and Behavioral Sciences 46 (2012): 2747-52. <https://doi.org/10.1016/j.sbspro.2012.05.559>. 
will not overwhelm the target, but still acknowledge that someone who gives the commandment should be respected and the target also know how to place themselves without feeling underestimated but being engaged to cooperate in protecting each other from things that should be avoided.

Islam considered that the human's mind is a gift from Allah that must be maintained as well as possible. ${ }^{35}$ Negative habits in social life need to be avoided by all means. For example, the problem of juvenile delinquency in Indonesia has recently entered a climax. In addition to increasing frequency and intensity, current delinquency has led to acts that violate norms, laws, and religion. Juvenile delinquency grows, develops and brings its own consequences throughout the period that are difficult to find a solution for. ${ }^{36}$ The prohibition of khamr or alcohol drinks is in accordance with Islamic teachings which want the formation of individuals who have physical, mental and intellectual strength. There is no doubt that alcohol can weaken the personality, potentials, especially healthy mind. ${ }^{37}$

In this case, the research conducted is applied in today's era, prevention of khamr and cigarette is carried out by Somali Muslims even during Ramadan. ${ }^{38}$ Quraish Shihab $^{39}$ explains that in Surah An-Nisa (4) verse 43, Allah strictly forbided intoxication but it had not been completed, because the prohibition is limited to the times before prayer. Then, in Surah Al-Maidah (5) verse 90 has prohibition and the last regarding khamr for all time. These are the steps taken by Al-Qur'an in forbidding liquor. From khamr, various kinds of sins arise that can harm the soul, body, mind, and wealth. ${ }^{40}$

35 Hamidullah Mahmud, 'Hukum Khamr Dalam Perspektif Islam', Journal of Islamic Family Law 1, no. 1 (2020): 28-47.

36 Taufikin, 'Hukum Islam Tentang Minuman Keras Pencegahan Dan Penanggulangan Perilaku Minuman Keras Di Desa Sidomulyo Kecamatan Dempet Kabupaten Demak', Yudisia 6, no. 2 (2015): 48299.

37 Winarno, 'Status Hukum Khamr Dalam Perspektif Fiqih Asyar'iyyah', Jurnal Ilmu Syari'ah Dan Perbankan Islam 3, no 1 (2018): 1-25.

38 Rebekah Pratt and others, 'Text Message Support for Smoking Cessation during Ramadan: A Focus Group Study with Somali Immigrant Muslim Men', Nicotine and Tobacco Research 22, no. 9 (2020): 1636-39. <https://doi.org/10.1093/ntr/ntz187>.

39 Muhammad Quraish Shihab, Tafsir Al-Misbah: Pesan, Kesan Dan Keserasian Al-Qur'an (Jakarta: Lentera Hati, 2001), 624.

40 Arif Jamaluddin Malik, 'Sejarah Sosial Hukuman Peminum Khamr', Al-Daulah: Jurnal Hukum Dan Perundangan Islam 3, no. 1 (2013): 42-56. <https://doi.org/10.15642/ad.2013.3.1.42-56>. 


\section{Conclusion}

In general, there are 3 ways of God conveying message to humans through prohibitions or commandment, the three appeals are as follows: First, conveying commandments are carried out gradually. Second, the substance conveyed in the message is very essential and fundamental. Third, the chosen context is adjusted to the understanding of the exclamation aspect. Conceptually, the type of nida in An-Nisa verse 43, and Al-Maidah verse 90 and 105 is letter "يا" which means an exclamation to those who are near or far. Based on characteristic of the verse, it is considered as Nida haqiqi, which is an exclamation which addressed to people who are smart, tamyiz, and having healthy mind, because basically the message of nida is only intended for people who have healthy mind. It is only an intelligent person who can receive and capture the message contained in nida. Then, the idea of this study becomes a bridge in character education through the approach that youth have an important role in building the society, the state, and civilization. In Al-Qur'an it was said that the verses of Allah are to convince humans that they are placed in glory even though they are going through the journey and trials of sin and mistakes. From these mistakes, human beings can prevent it from each other so that ultimately from these mistakes humans can remind each other. Furthermore, this research hoped there would be the further studies on the concept of character education in the context of language studies. The weakness of this research was lacking the verses that would be studied. Hopefully, the further research can be continued by enriching the other verses of Al-Quran.

\section{Acknowledgment}

Researchers would like to thank all of parties, especially to the Department of Arabic Language Education, Faculty of Language and Literature Education, Universitas Pendidikan Indonesia. In addition, the researchers would like to thank the research team and students who involved in this research.

\section{References}

Anshori, Muhammad, 'Pemuda Dalam Al-Qur'an Dan Hadis', Jurnal Kajian Islam Interdisipliner 1, no.2 (2019): 227-252.

Arsal, 'Metode Hermeneutika Dan Tafsir Alquran', Alhurriyah : Jurnal Hukum Islam 2, 
no. 2 (2017): 1-16.

Asayesh, Mohammad Hassan, and Bahramizadeh Hamid, 'Examination of Personal Values System and Its Changes among Young People', Procedia - Social and Behavioral Sciences $\quad 30 \quad$ (2011): <https://doi.org/10.1016/j.sbspro.2011.10.270>

Ashar, Ashar, 'Konsep Khamar Dan Narkotika Dalam Al-Qur'an Dan UU', Fenomena 7, no. 2 (2015): 273-96. <https://doi.org/10.21093/fj.v7i2.313>

Baharuddin, Sakinah Fitrianti, 'Pendekatan Semantik Dalam Al-Quran (Studi Makna Terhadap Ayat-Ayat Kosmologi)', Shaut Al Arabiyyah 6, no. 2 (2019): 177. <https://doi.org/10.24252/saa.v6i2.7162>

Darsitun, Darsitun, 'Menakar Ulang Hermeneutika Dalam Studi Alquran Di Era Modern Dan Kontemporer (Pendekatan Sastra, Sejarah Dan Sains)', Islamadina: Jurnal $\begin{array}{llllll}\text { Pemikiran Islam } & 22, \quad \text { no. } & 1 & \text { (2021): }\end{array}$ <https://doi.org/10.30595/islamadina.v22i1.6899>

Hamidi, Farideh, and Zohreh Bagherzadeh, 'Role and Place of Guidance Teacher in Schools', Procedia - Social and Behavioral Sciences 5, no. 2 (2010): 1918-21. <https://doi.org/10.1016/j.sbspro.2010.07.388>

Hanafi, Wahyu, 'Stilistika Alquran: Ragam Bahasa Ayat-Ayat Talab Dalam Diskursus Stilistika', Jurnal Al-Mabsut: Jurnal Studi Islam Dan Sosial 11, no. 1 (2018): 1-19.

Hardian, Novri, 'Dakwah Dalam Perspektif Al-Qur'an Dan Hadits', Al-Hikmah: Jurnal Dakwah Dan Ilmu Komunikasi 5, no. 1 (2018): 42-52. <https://doi.org/10.15548/alhikmah.v0i0.92>

Haris, Abdul, 'Panggilan Quran Kepada Umat Manusia', Jurnal Pemberdayaan Masyarakat 6, no. 1 (2018): 15. <https://doi.org/10.37064/jpm.v6i1.4985>

Hizbullah, Nur, 'Program Kajian Bahasa Arab Al Qur'an Dan Pemahamannya Dengan Metode Komprehensif', Jurnal Al-Azhar Indonesia Seri Humaniora 1, no. 4 (2014): 267. <https://doi.org/10.36722/sh.v1i4.77>

Hoover, David L., 'Authorship and Stylistics', The Encyclopedia of Applied Linguistics (2015): 1-7. <https://doi.org/10.1002/9781405198431.wbeal1457>

Irfan, 'Interpretation of Amanah Verses in the Qur' an Penafsiran Ayat-Ayat Amanah Dalam Al- Qur' an', Ilmu Al-Qur'an Dan Tarfsir 4, no. 2 (2019): 113-28. $<$ https://doi.org/10.30868/at.v4i02.571>

Ismatulloh, A.M., 'Ayat-Ayat Hukum Dalam Pemikiran Mufasir Indonesia (Studi Komparatif Penafsiran M.Hasbi Ash-Shiddieqi Dan M.Quraish Shihab)', Fenomena 6, no. 2 (2014): 277. <https://doi.org/10.21093/fj.v6i2.555>

Istianah, 'Stilistika Al-Qur'an: Pendekatan Sastra Sebagai Analisis Dalam Menginterpretasikan Al-Qur'an', Hermeneutik 8, no. 2 (2014): 369-88. 
Jeffries, Lesley, 'Stylistics', The International Encyclopedia of Anthropology (2018): 2. <https://doi.org/10.1002/9781118924396.wbiea1388>.

Karem, Al Fowehi Hazaa Abdul, Kamisah Osman, and T. Subahan Mohd Meerah, 'The Impact of Module Based Curriculum and Extra-Curriculum Activities' in Developing Environmental Skills among Saudi's Secondary Students', Procedia Social and Behavioral Sciences 15 (2011): 1756-60. <https://doi.org/10.1016/j.sbspro.2011.03.364>

Khitam, Achmad Khusnul, 'At-Tanāwub, At-Taqdīm Wa At-Ta'khīr, Dan Al-Iltifāt (Kajian Stilistika Al-Qur'an Dan Puisi Arab)', Mukaddimah: Jurnal Studi Islam 2, no. 1 (2017): 1-18.

Lin, Benedict, 'Stylistics in Translation', The Cambridge Handbook of Stylistics (2015): 573-89. <https://doi.org/10.1017/CBO9781139237031.042>

Mahmud, Hamidullah, 'Hukum Khamr Dalam Perspektif Islam', Journal of Islamic $\begin{array}{llllll}\text { Family Law } & 1, & \text { no. } & 1 & \text { (2020): }\end{array}$ <http://ejournal.iainpalopo.ac.id/index.php/maddika>

Malik, Arif Jamaluddin, 'Sejarah Sosial Hukuman Peminum Khamr', Al-Daulah: Jurnal Hukum Dan Perundangan Islam 3, no. 1 (2013), 42-56. <https://doi.org/10.15642/ad.2013.3.1.42-56>

Muhammad Hafidz, 'Memahami Balaghah Dengan Mudah', Ta'limuna 7, no. 2 (2018): $1-17$.

Mun'im, A Rafiq Zainul, 'Tafsir Realis Terhadap Makna Dan Simbol Alquran Bagi Masyarakat Kabupaten Probolinggo', Madania: Jurnal Kajian Keislaman 21, no. 2 (2017): 193. <https://doi.org/10.29300/madania.v21i2.624>

Nycz, Jennifer, 'Stylistic Variation among Mobile Speakers: Using Old and New Regional Variables to Construct Complex Place Identity', Language Variation and Change 30, no. 2 (2018), 175-202. <https://doi.org/10.1017/S0954394518000108>

Pratt, Rebekah, Olamide Ojo-Fati, Asma Adam, Hiba Sharif, Abdillahi Kahin, Abdirahman Mahamud, and others, 'Text Message Support for Smoking Cessation during Ramadan: A Focus Group Study with Somali Immigrant Muslim Men', Nicotine and Tobacco Research 22, no. 9 (2020): 1636-39. <https://doi.org/10.1093/ntr/ntz187>

Reza Mahmoudi, Mohammad, and Ali Abbasalizadeh, 'Statistical Analysis about the Order of Quran's Revelation', Digital Scholarship in the Humanities 34, no. 1 (2019): 152-58. <https://doi.org/10.1093/llc/fqy030>

Setiawan, Daryanto, 'Ilmu Pengetahuan Dalam Al-Qur'an', Al Hadi 3, no. 2 (2018): 641-56.

Shihab, Muhammad Quraish, Tafsir Al-Misbah: Pesan, Kesan Dan Keserasian AlQur'an, Jakarta: Lentera Hati, 2001. 
Syukriya, Alvi Jauharotus, and Hayyun Durrotul Faridah, 'Kajian Ilmiah Dan Teknologi Sebab Larangan Suatu Makanan Dalam Syariat Islam', Journal of Halal Product and Research 2, no. 1 (2019): 47-48.

Tasdemir, Adem, Tezcan Kartal, and Zafer Kus, 'The Use of Out-of-the-School Learning Environments for the Formation of Scientific Attitudes in Teacher Training Programmes', Procedia - Social and Behavioral Sciences 46 (2012): 2747-52. <https://doi.org/10.1016/j.sbspro.2012.05.559>

Taufikin, 'Hukum Islam Tentang Minuman Keras Pencegahan Dan Penanggulangan Perilaku Minuman Keras Di Desa Sidomulyo Kecamatan Dempet Kabupaten Demak', Yudisia 6, no.2 (2015): 482-99.

Uitto, Anna, Jelle Boeve-de Pauw, and Seppo Saloranta, 'Educational Factors Explaining 9th Graders Self-Efficacy in Ecological Sustainable Behaviours', Proceedings of the European Science Education Research Association (2013): 1623-1631.

Voinea, C.F, 'Advances in the Simulation-Based Analysis of Attitude Change', European Quarterly of Political Attitudes and Mentalities (EQPAM) 1, no. 1 (2012): iv-xi.

Wakka, Ahmad, 'Petunjuk Al-Qur'an Tentang Belajar Dan Pembelajaran (Pembahasan Materi, Metode, Media Dan Teknologi Pembelajaran)', Education and Learning Journal 1, no. 1 (2020): 86-92.

Winarno, 'Status Hukum Khamr Dalam Perspektif Fiqih Asyar'iyyah', Jurnal Ilmu Syari'ah Dan Perbankan Islam 3, no. 1 (2018): 1-25.

Zain, Arifin, Maimun, and Maimun Fuadi, 'Identifikasi Ayat-Ayat Dakwah', Al Idarah: Jurnal Manajemen Dan Administrasi Islam 1, no. 2 (2017): 167-88.

Zaini, Ahmad, 'Asbab An-Nuzul Dan Urgensinya Dalam Memahami Al-Quran', Hermeunetik 8, no. 1 (2014): 1-20.

Zamakhsyari, H, and Hasballah Thaib, 'Tadarus Al-Qur'an: Urgensi, Tahapan, Dan Penerapannya', Almufida 1, no. 1 (2016): 21-48.

Zulfikar, Eko, 'Interpretasi Makna Riya' Dalam Al-Qur'an: Studi Kritis Perilaku Riya' Dalam Kehidupan Sehari-Hari', Al-Bayan: Jurnal Studi Ilmu Al-Qur'an Dan Tafsir 3, no. 2 (2019): 143-57. <https://doi.org/10.15575/al-bayan.v3i2.3832> 